\title{
Nigeria: Positioning Rural Economy for Implementation of Sustainable Development Goals
}

\section{Akinbode Michael Okunola*}

Department of Agricultural and Resource Economics, Federal University of Technology, Akure, Ondo State, Nigeria A R T I C L E I N F O

\section{Article history:}

Received 17 June 2016

Accepted 21 July 2016

Available online, ISSN: 2148-127X

\section{Keywords:}

Poverty

Sustainable development

Rural economy

SDGs

Agriculture

${ }^{*}$ Corresponding Author:

E-mail: okunolakinbode@gmail.com

\section{A B S T R A C T}

Nigeria as nation has over the years engaged in lots of developmental activities without actions which makes achievements to elude the people. Development of societies doesn't happen in the vacuum. Thus, the adoption of Structural Adjustment Program, SAP, by Nigeria leading to the neglect of the custom periodic National Plan at a time when Nigeria had no structure for development was the beginning of journey to widened inequality and large poverty incidence, depth and severity. To close the gap between the rich and the poor, the Nigeria government had designed and implemented some programs and policies whose implementation has not solved the inherent problems. In year 2000, the world leaders subscribed to the Millennium Development Goals to ensure synergized global approach to solving the poverty menace. Programs designed in Nigeria to achieve the MDGs focused on the urban centers thereby relegating the rural areas which are responsible for the feeding of the teeming population of the urban dwellers. Farming households and the general rural communities do not have access to clean water, quality education and health facilities, good feeder roads, affordable and safe energy as well as other socioeconomic and socio-infrastructural facilities that would ensure sustainable living for the people whose contribution to the national economy cannot be overemphasized. This study therefore looks at the structural actions the Nigeria government should embarked upon to ensure that the rural dweller have access to life. As the government would be developing programs and policies to achieve the Sustainable Development Goals whose priority is the end poverty in all forms and everywhere by 2030, this study reveals how to position the rural economy for developmental attention from the policy makers.

\section{Introduction}

Poverty is a multi-dimensional societal phenomenon in which people cannot actively live their desired lives, explore resources to make a living for themselves - a situation which incapacitate them from active participation in the socioeconomic and socio-political equations of their society. United Nations (1995) adopted two definitions of poverty: Absolute poverty, a situation conditioned by severe deprivation of basic human needs, including food in appropriate quantity and quality, safe drinking water, sanitation facilities, health, shelter, education and information. It depends not only on income but also on access to services. On the other hand, Overall poverty in its multi-conceptual forms, including lack of source of income and productive resources to ensure sustainable living, hunger and malnutrition, ill health, limited or lack of access to fundamental education, increased morbidity and mortality from illness, homelessness and inadequate housing, unsafe environments and social discrimination and exclusion. It is also characterized by lack of participation in decision making and in civil, social and cultural life. WeisfeldAdams and Andrzejewski (2008) revealed that according to the World Bank (2008), people living on less than US\$1 per day are living in extreme poverty, and people who earn less than US\$2 a day are in moderate poverty. The study further stated that UNDP (2007) revealed that approximately one billion people live on less than US\$1 a day. About 2.6 billion live on less than US\$2 a day. This amounts to $40 \%$ of the world's population. In SubSaharan Africa, $41 \%$ of the population lives on less than US\$1 a day (Population Reference Bureau, 2006).

Poverty reduction has received increased focus in development debate in the past two decades. Progress on poverty reduction has become a major measure of success of development policy. In the 1970s and 1980s, the preoccupation was with growth, the need to grow the economies and incomes. Thus, growth was seen as a prerequisite for improved welfare. Many developing countries in the 1980s implemented structural adjustment programmes (SAP) aimed at enhancing growth. Following these programmes, many countries recorded positive real growth rates. The development literature in the 1990s was dominated by the view that growth is central to any strategy aimed at poverty reduction. Studies suggest that countries that made noticeable progress on poverty reduction were those which recorded fast and high growth rates (World Bank 2000, Dollar and Kraay 2000). 
Across the globe, especially in third world countries, people wallow in abject poverty - a cankerworm against growth and development. Sometimes, people go to bed with empty stomach without hope of what to eat the following day and perhaps, malnutrition becomes customary. Some don't have shelter over their heads; health care delivery system and electricity are alien to some communities; pipe borne water, lack of qualitative or limited access to or total lack of education and endemic diseases has taken over some territories; lots of mothers and children die during child birth on a daily basis, some environment are not conducive to human habitation due to environmental degradation; while some still live in the stone age societies where there is basically no form of civilization, presence of social discrimination and exclusion as well as the lack of participation in decision making. There are many developing countries in the world with precarious development indices. For example, it is said that more than 1.2 billion people or about 20 per cent of the world population live or survive on less than US 1 per day (Shetty, 2005).

The fight against poverty has been a central plank of development planning since independence in 1960 and about fifteen ministries, fourteen specialized agencies, and nineteen donor agencies and non-governmental organizations have been involved in the decades of this crusade but about 70 per cent of Nigerians still live in poverty, (Soludo, 2003). Literatures have unanimously agreed that successive government's interventions have failed to achieve the objectives for which they were established (Ovwasa, 2000; Adesopo, 2008; Omotola, 2008). The failure to effectively combat the problem has largely been blamed on infrastructural decay, endemic corruption, and poor governance and accountability (Okonjo-Iweala, et al 2003).

\section{Poverty and Nigeria's Intervention}

In Africa, poverty remains a scourge that undermines development in contemporary societies because it is deeprooted and pervasive (Igbatayo and lgbinedion, 2006). In Nigeria as it is inherent in other African nations, the twin issues of poverty and inequitable income distribution present a paradox. This is so because, though the country is rich in land, human and natural resources, the people are still considered to be poor, as nearly 70 per cent of Nigerians in 1999 were living in poverty (FOS, 1999; Okojie, et al., 2000; World Bank, 2000; Soludo, 2006), while the incidence of poverty has remained relatively high, hovering around 54 per cent between 2005 and 2009 (CBN, 2009). Worse still, the problems of poverty in Nigeria are multi-faceted, among which are widespread outbreak of AIDS pandemic, lack of access to good health facilities, high infant mortality rate, lack of essential infrastructure, unemployment and underemployment, corruption, etc.

As cited in (Oladimeji, 2005), with the recognition by the Nigerian government of the multi-sectored and multidimensional nature of poverty, a number of coordinated programmes and policies had been formulated to combat poverty in all its ramifications. These policies and programmes include the National Accelerated Food Production Project (NAFPP, 1972), the National Poverty Eradication Programme (NAPEP), the National Accelerated Food Production Project (NAFPP), Operation Feed the Nation (OFN, 1976), Green Revolution Program (1980), the National Economic Empowerment and Development Strategy (NEEDS), Directorate of Food, Roads and Rural Infrastructure (1986), National Fadama Development Project (1992), Green Revolution Program (1980), Directorate of Food, Roads and Rural Infrastructure (1986) and the Millennium Development Goals.

As cited in Abur et al. (2013), the incidence of poverty increased from 1985-2006. However, there was a decline in poverty level between 1995-1999. 28.1 per cent people lived in poverty in 1985 , a situation which later rose to 46.3 per cent in 1995 but decreased to 42.7 per cent in 1999 before rising to 65.6 per cent in 2006 again. Nevertheless, the proportion of people living in poverty declined to 54.4 per cent in 2011 (Bello, 2007). This translated to 17.7 million and 34.7 million poor people in 1985 and 1995 respectively. The poverty population of Nigeria also increased from 39.2 million people in 1999 to 67.1 million people in 2006 , and 68.7 million people in 2011. In spite of the observed drop in poverty in 1999 and 2011, the population in poverty was 4.5 million higher than the 1995 figure and 1.6 million higher than that of 2006 figure respectively (Federal Republic of Nigeria, 2010).

\section{Poverty Eradication and the Millennium Development Goals}

As a result of these observed phenomena in almost all developing economies of the world, there was a consensus call for global approach to the problem and solution to poverty worldwide. Therefore after keen observation and deliberation, the international community decided to present common goals towards poverty eradication globally. This is what brought about the subject matter Millennium Development Goals. According to Osundina et al (2013), with the recognition of poverty as a common denominator in the global community, the Millennium Development Goals (MDGs) were adopted in September 2000 by 189 world leaders. The overall goal of the Millennium Declaration which gave birth to the Millennium Development Goals was a reinstatement of commitment to free all men, women and children from the abject and dehumanizing conditions of extreme poverty by the year 2015 . With reference to subSaharan Africa including Nigeria, the inauguration of the Millennium Development Goals more or less represents an exit strategy from poverty trap. The global partnership for development which constitutes the substance of goal 8 reflects the commitment of the industrialized world to the fight against poverty in the developing world through official development assistance. The specific objectives of the MDGs are arranged in the Table 1. 


\section{Poverty Eradication and Sustainable Development Goals}

As the world leaders have made another declaration in the name of Sustainable Development Goals to see that among others, poverty is ended in all its forms everywhere, the United Nations have set out new seventeen (17) Sustainable Development Goals and one hundred and sixty-nine (169) targets. In recognizing that finding a lasting solution to the issue of poverty is the key to sustainable development, the preamble of the declaration document says "We recognize that eradicating poverty in all its forms and dimensions, including extreme poverty, is the greatest global challenge and an indispensable requirement for sustainable development." To show their resilience towards a safe world, the Heads of Governments of the world said "We are resolved to free the human race from the tyranny of poverty and want and to heal and secure our planet. We are determined to take the bold and transformative steps which are urgently needed to shift the world on to a sustainable and resilient path. As we embark on this collective journey, we pledge that no one will be left behind" (United Nations SDGs Declaration Document, A/RES/70/1).

Declaration 2 of the document says "On behalf of the peoples we serve, we have adopted a historic decision on a comprehensive, far-reaching and people-centered set of universal and transformative goals and targets. We commit ourselves to working tirelessly for the full implementation of this Agenda by 2030. We recognize that eradicating poverty in all its forms and dimensions, including extreme poverty, is the greatest global challenge and an indispensable requirement for sustainable development. We are committed to achieving sustainable development in its three dimensions - economic, social and environmental - in a balanced and integrated manner. We will also build upon the achievements of the Millennium Development Goals and seek to address their unfinished business." The Sustainable Development Goals are therefore listed in the table 2.

From table 2, it is obvious that the Goals $1-8$ are reflecting the aggressiveness of the world leaders to see that everyone has access to life and achieve personal desire to meet the basic needs of life. Therefore, it must be a largely accepted fact that agriculture as an economic sector has the potency to provide jobs for people, ensure food security as well as improve the overall economy of every nation. Hence the need for the governments of the world to realize that achieving the SGDs should go beyond paper declaration. Policies and programs that will create enabling agribusiness environment as well as empower the farmers who are responsible for the feeding of several millions over the world to have access to basic social amenities such as quality health service, road linkages from their homes to farms and from farms to the market, electricity, good water, etc., all at reasonable distances should be embarked upon.

Table 1 The specific objectives of the MDGs

\begin{tabular}{|c|c|}
\hline $\mathrm{S} / \mathrm{N}$ & Goal \\
\hline 1 & To eradicate extreme poverty and hunger \\
\hline 2 & Achieve universal access to education \\
\hline 3 & Promote gender equality and empower women \\
\hline 4 & Reduce infant and child mortality \\
\hline 5 & Improve maternal health \\
\hline 6 & Combat HIV/AIDS malaria and communicable diseases \\
\hline 7 & Ensure environmental sustainability \\
\hline 8 & To develop a global partnership for development \\
\hline
\end{tabular}

Source: (Osundina et al., 2013)

Table 2 The specific objectives of the SDGs

\begin{tabular}{c|l}
\hline No & Goal \\
\hline 1 & End poverty in all its forms everywhere \\
2 & End hunger, achieve food security and improved nutrition and promote sustainable agriculture \\
4 & Ensure healthy lives and promote well-being for all at all ages \\
5 & Ensure inclusive and equitable quality education and promote lifelong learning opportunities for all \\
6 & Achieve gender equality and empower all women and girls \\
7 & Ensure availability and sustainable management of water and sanitation for all \\
8 & Ensure access to affordable, reliable, sustainable and modern energy for all \\
9 & Build resilient infrastructure, promote inclusive and sustainable industrialization and foster innovation \\
10 & Reduce inequality within and among countries \\
11 & Make cities and human settlements inclusive, safe, resilient and sustainable \\
12 & Ensure sustainable consumption and production patterns \\
13 & Take urgent action to combat climate change and its impacts \\
14 & Conserve and sustainably use the oceans, seas and marine resources for sustainable development \\
15 & Protect, restore and promote sustainable use of terrestrial ecosystems, sustainably manage forests, combat desertification, \\
& and halt and reverse land degradation and halt biodiversity loss \\
16 & Promote peaceful and inclusive societies for sustainable development, provide access to justice for all and build effective, \\
17 & accountable and inclusive institutions at all levels \\
\hline Source: & Strengthen the means of implementation and revitalize the Global Partnership for Sustainable Development \\
\hline
\end{tabular}




\section{Agriculture and Poverty Alleviation}

As cited in Byerlee et al (2005), Diao et al (2005) stated that based on 33 household survey in India from 1957 to 1990, Ravallion and Dati (1996) found out there is a strong evidence that agricultural development causes reduction in poverty in the urban and rural communities. Thorbecke and Jung (1996) using social accounting matrix for Indonesia found that the agricultural sector contributes the most to overall poverty reduction. Using data from 1985 to 1996 for China, (Fan et al., 2005) estimated an econometric model to compare the relative contributions of rural and urban agricultural growth to poverty reduction in those areas. The authors discovered that higher growth in agriculture reduced both rural and urban poverty. Based on data from a broad sample of developing countries in the early 1970 and mid-1980s, Bourguignon and Morison (1998), using cross-country regressions for each time period separately and therefore the pooled data observed that increasing agricultural productivity was the most effective path for many countries to reduce poverty and inequality.

To bring poverty to its knees, the Nigerian government has over time before the Millennium Development Goals developed agricultural programs and policies aimed at taking the people out of poverty by ensuring food security, harness the employability of the agricultural sector to provide jobs to the teeming unemployed, especially the youths. As noted by Okunola (2016), in Nigeria, agricultural policies and programs have undergone changes especially in the postcolonial era. These changes have been a mere reflection of changes in government or administration. This is because these policies and programs vary only in nomenclature and organizational network. They emphasize almost same objectives like: to provide food, for the inhabitants of the nation (food security and sufficiency) and export excess to other countries and to provide rural dwellers and farmers with extension services, agricultural support and rural development services etc. Despite all the policies and laudable programs with challenging themes, Nigeria is yet to achieve food security. Agriculture also continues to suffer from inertia associated with these policies and program reformation that pervade Nigeria, Amalu (1998).

According to Jibowo (2005) in Okunola (2016), some national agricultural programs that were established and implemented following Nigeria's political independence in 1960 and the subsequent establishment of the Federal Ministry of Agriculture in 1970 included:

- National Accelerated Food Production Project (NAFPP, 1972)

- River Basin Development Authorities (1973)

- Agricultural Development Projects (1975)

- Operation Feed the Nation (OFN, 1976)

- Agricultural Credit Guarantee Scheme (1977)

- Green Revolution Program (1980)

- Nigerian Agricultural Insurance Scheme (1985)

- Directorate of Food, Roads and Rural Infrastructure (1986)

- National Fadama Development Project (1992)

- National Special Program for Food Security (2002)
Examining the programs which have stood the test of time, i.e., changes in administration and structural consistency, Okunola (2016) listed the following as the programs which are still existing since their creation:

- $\quad$ River Basin Development Authorities (1973)

- Agricultural Development Projects (1975)

- Agricultural Credit Guarantee Scheme (1977)

- Nigerian Agricultural Insurance Scheme (1985)

- National Fadama Development Project (1992) (The last phase Fadama III came to an end, December, 2013).

Adducing the reason for the continuous existing of these programs, the study said that it is either the programs are co-sponsored by the Federal Government of Nigeria and a donor agency like World Bank in the case of Agricultural Development Projects (1975) and National Fadama Development Project (1992) or the use of the instrument of law making in the case of River Basin Development Authorities (1973), Agricultural Credit Guarantee Scheme (1977) and Nigerian Agricultural Insurance Scheme (1985).

\section{Positioning Rural Economy for Sustainable Development}

As sustainable development has been summarized to be continuous access to basic needs of life including capital market to ensure that the people can be economically, socially and politically active in their society, it is therefore pertinent that the rural economy whose main business is agriculture should be given adequate developmental attention in the areas of creation of enabling business environment for their agricultural activities, provision of socioeconomic facilities to stem the rate of rural-urban migration and also give the rural dwellers access to life.

Agriculture as an economic sector possesses great potentials to lift many out of poverty in Nigeria if only the government will do the needful. Rural-inclined sustainable agricultural programs and policies have to be developed to empower the rural areas. There was greater concentration on the urban center development in the implementation of the Millennium Development Goals in Nigeria. Many of primary education interventions was in the urban centers leaving the children of the farmers who are responsible for the feeding of the urban dwellers in abject illiteracy. Many rural areas lack quality health centers and the wives of the farmers are delivered of their pregnancies by local midwives as there are no nearby hospitals in case of any emergency situation, while in some cases, hospitals don't exist. The agrarian communities do not have access to good water and they are left with unhealthy cooking means which have negative impacts on their health and the environment. The farmers lack access to basic market information and the middlemen take advantage the situation to become price givers. Hence, the farmers don't have maximum revenue from their farm investments. There are also no storage 
facilities for the farmers to store excess produce for future sale during the off-season. These in all incapacitate the farmers in the rural areas and relegate them in the economic schemes of the country. Therefore, the Nigerian government must rise to the occasion to empower the rural dweller in all ways to give them confidence about their business, hope for the future of their children and access to good and quality life.

To achieve sustainable development of the rural areas, the government must ensure national, rational and peopleoriented agricultural development. The agricultural programs that will ensure flow of agricultural credits to the rural farmers should be embarked upon. The rural farmers do not have the required collateral to access commercial bank loans. Hence, provision should be made for enough credit to the small holder farmers in the rural areas. At the moment, the agricultural credit offered through the Bank of Agriculture to small holder farmers is not enough for agricultural production. In fact, such credits are not enough to take the farmers from preparation of farmlands to harvesting. Hence, the Bank of Agriculture should be further strengthened to ensure flow of enough agri-credit to the farmers in the rural areas to increase their production capacities and by extension, food production in the country.

The government should also embark on massive socio-infrastructural development of the rural areas. Quality primary and secondary schools with quality teachers and teaching materials should be provided for the rural dwellers. This will stem the rate at which the children of the farmers embark on rural-urban migration in search of a better life than that of their parents. Quality health centers should also be provided for the rural areas and within reasonable distances. This will stem the rate of birth mortality due to crude and traditional means of delivery of pregnant rural women. It will also guarantee good life as the rural dweller can check up on the status of their health and this raise the life expectancy in Nigeria. The government at all levels should also ensure that the feeder roads connecting the rural areas with the urban centers are improved upon to ensure easy access to the rural markets by the urban dwellers as this will improve on the income of the rural dwellers and afford them the opportunity to access the basic needs of life as they desire and can afford to possess.

The government should engage the rural dweller on the importance of environmental protection with the use of safe energy means in their cooking. The rural dweller rely mostly on the fire woods which are mainly from felled trees that expose the environment to climatic dangers. Apart from exposing the environment to danger by felling trees, using fire woods for cooking has health hazards on the people in the rural areas. Hence, the government and non-governmental organizations should embark on social awareness program to intimate the rural dweller on the use of gas cookers which will not just protect the environment and the health of the rural dwellers but would also enable the people to save money that would rather have been used to purchase soaps to do washing of black pots and plates.,

\section{Conclusion}

This study has been able to establish that no meaningful development will happen in the agricultural sector of the Nigerian economy without programs and policies that can stand the test of time and outlive the administrations that established them. Nigeria as a nation have suffered from inconsistency in programs and policies in the agricultural sector due to changes in government over the years. This study has also established the main reason behind the program and policies that are still existing in Nigeria to be the legislative framework provided for them and hence it is almost impossible for any government to discard for political or other reasons. Aligning with the conclusion of Okunola (2016), legislative arm of government of Nigeria has crucial roles to play in sustainable development of the rural areas by providing legislative framework for programs and policies that have proved their worth or whose prospects are bright to insulate them from inconsistency.

The legislature should ensure that the executive provide for budgetary allocation for socioeconomic and socio-infrastructural development of the rural areas in Nigeria and should ensure oversight function for maximum implementation of the budget in the interest of rural dwellers. The legislature should also ensure that it provides frameworks for rural interventions of the executive to allow for sustainability of such interventions. The government should ensure that in the implementation of programs and policies that will be developed toward achieving the sustainable development goals, the rural areas are not neglected as they are crucially important to the future of Nigeria and her people. As the nation would look forward to lift people out of poverty within the time frame of this new developmental goals, agriculture with its enormous proven potentials should be explored to restore the lost economical agricultural prowess of the agrarian Nigeria.

Finally, the government should develop fiscal policy in taxes and subsidies that will empower the farmers in the rural areas and as well as serve as incentives for those who have given almost all of their lives to farming to feed the teeming population. Reduced personal income tax, business tax as well as subsidized input will encourage the farmers to put more efforts into production. Such polices will also ensure accumulation of more income to the farming households and thus allow them to access more basic amenities such as health centers for medical check-ups and quality education for their children and also afford to conveniently feed their households.

\section{References}

Abur CC, Eche E, Torruam JT. 2013. Millennium Development Goals (Mdgs) and Poverty Reduction in Nigeria. International Journal of Basic and Applied Science, Vol. 01, No. 03: 504510.

Amalu UC. 1998. Agricultural Research and Extension Delivery systems in Sub Saharan Africa, Calabar: University of Calabar Press. 
Adesopo A. 2008. 'The Poverty Question And The National AntiPoverty Programmes In Nigeria?' In K. Ajayi (Ed), Public Administration and Public Policy Analysis in Nigeria, 213-227. Abuja: Panaf Publishing Inc.

Bello AM. 2007. The Activities of the Agency. Paper Delivered At A Two Day Capacity Building Workshop On The Theme. Child Trafficking and Child Labour. Organized By Nigerian Agency For Prohibition Of Trafficking In Persons And Other Related Matters (NAPTIP) Kano.

Bourguignon F, Morrisson C. 1998. "Inequality and Development: The Role of Dualism.” Journal of Development Economics 57: 233-258.

Byerlee D, Diao X, Jackson C. 2005. Agriculture, Rural Development, and Pro-poor Growth - Country Experiences in the Post- Reform Era. Agriculture and Rural Development Discussion Paper: 21

CBN 2009. Central Bank of Nigeria, Annual Report and Statement of Accounts, vi

Dollar D, Kraay A. 2000. Growth Is Good For the Poor", World Bank (Mimeo) (March).

Diao X, Hazell P, Resnick D, Thurlow J. 2005. "The Role of Agriculture in Pro-Poor Growth in Sub-Saharan Africa." Processed, IFPRI, Washington, D.C.

Fan S, Chan-Kang C, Mukherjee A. 2005. "Rural and Urban dynamics and poverty: Evidence from China and India." Draft Paper, IFPRI, Washington, D.C.

Federal Republic of Nigeria. 2010. Millennium Development Goals Information Kit.

FOS. 1999a. Federal Office of Statistics, Poverty Profile for Nigeria, 1980-1996. Lagos, 24.

FOS. 1999b. Federal Office of Statistics, Annual Abstract of Statistics, 1999 Edition.

Igbatayo SA, Igbinedion, SO. 2006: The Challenges of Poverty Reduction in Sub-Saharan Africa: The South African Experience. Journal of Business Administration and Management. Vol. 1, Number 1, Duncan Science Journals, 35.

Jibowo AA. 2005. "History of Agricultural Extension in Nigeria" In: Adedoyin S.F (ed) Agricultural Extension in Nigeria, Ilorin (AESON).

Okojie CEE, Anyanwu JC, Ogwumike PO, Alayande BA. 2000. Poverty in Nigeria: An Analysis of Gender Issues, Access to Social Services and the Labour Markets. A Draft Report to the African Economic Research Consortium (AERC), Nairobi, Kenya.

Okonjo-Iweala N, Soludo CC, Muhtar M. 2003. 'Introduction', In N. Okonjo-Iweala, C. C. Soludo, M. Muhtar (Eds) The Debt Trap In Nigeria: Towards A Sustainable Debt Strategy, Pp. 1 19. Trenton, Africa World Press, Inc.

Okunola AM. 2016. Role of Legislature in Sustainable Agricultural Development in Developing Nations: A Case Study of Nigeria. Turkish Journal of Agriculture - Food Science and Technology, 4(5): 330-335.
Oladimeji YU. 2005. Analysis of Poverty Status of Rural Artisanal Fisherfolks in Kwara State, Nigeria. Unpublished Ph.D. Thesis. Ahmadu Bello University, Zaria, Nigeria.

Omotola JS. 2008. 'Combating Poverty for Sustainable Human Development in Nigeria: The Continuing Struggle', Journal of Poverty, 12(4): 496-517.

Osundina KC, Lawal, EO, Adesuyi OO. 2013. Millennium Development Goals and Poverty in Nigeria - An Empirical Analysis. Developing Country Studies. Vol.3, No.8: 94-104.

Ovwasa OL. 2000. 'Constraints on Poverty Alleviation in Nigeria,' Political Science Review. Official Journal of the Department Of Political Science, University of Ilorin, Nigeria 1(1): 56-80.

PRB. 2006. Population Reference Bureau 2006 Population Data Sheet. Washington D.C.

Soludo CC. 2003. 'Debt, Poverty And Inequality: Toward An Exit Strategy For Nigeria And Africa', In N. Okonjo-Iweala, C. C. Soludo, And M. Muhtar (Eds) The Debt Trap in Nigeria: Towards A Sustainable Debt Strategy, 23-74. Trenton, Africa World Press, Inc.

Soludo CC. 2006. Can Nigeria Be The China of Africa? Being a Lecture Delivered At the Founder's Day of the University of Benin, Nigeria; Nov. 23.

Shetty S. 2005. Millennium Declaration and Development Goals: Opportunities for Human Rights, International Journal of Human Rights, Year 2, No. 2.3.

Ravallion M, Datt G. 1996. How Important to India's Poor is the Sectoral Composition of Economic Growth? World Bank Economic Review, 10, 1-25.

Thorbecke E, Jung H. 1996. A Multiplier Decomposition Method to Analyze Poverty Alleviation. Journal of Development Economics. 48: 279-300.

UN. 1995. United Nations Copenhagen Declaration and Programme of Action, World Summit for Social Development, 6-12 March 1995, New York, United Nations.

UN. 2016. United Nations Declaration Document On The Sustainable Development Goals: www.sustainabledevelopment.un.org.

UNDP 2007. United Nations Development Programme Human Development Report. Washington D.C.

Weisfeld-Adams E, Andrzejewski A. 2008. The Hunger Project. 5 Union Square West, New York, NY 10003. www.thp.org (accessed on July 21, 2016)

World Bank. 2000. Attacking Poverty, World Development Report 2001/2002, New York, Oxford University Press.

World Bank. 2008. Understanding Poverty. http://web.worldbank.org/WBSITE/EXTERNAL/TOPICS/EXT POVERTY/0,,contentMDK:20153855 menuPK:373757 pageP K:148956 piPK:216618 theSitePK:336992,00.html (accessed on April 15th, 2008). 